\title{
'Data Baru' Dari Distribusi Artefak Prasasti
}

\section{Bugie Kusumohartono}

Keywords: inscription, spatial, distribution, method, theory

\section{How to Cite:}

Kusumohartono, B. 'Data Baru' Dari Distribusi Artefak Prasasti. Berkala Arkeologi, 14(2), 17-21. https://doi.org/10.30883/jba.v14i2.635

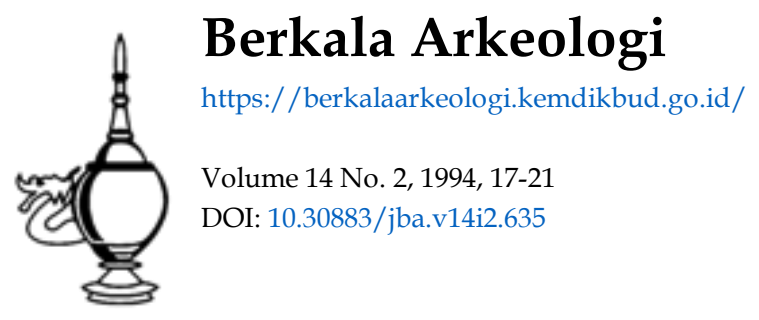

\section{(c) (i) 8 (2)}

This work is licensed under a Creative Commons Attribution-NonCommercial-ShareAlike 4.0 International License. 


\title{
'DATA BARU' DARI DISTRIBUSI ARTEFAK PRASASTI
}

\author{
Bugie Kusumohartono \\ (Balai Arkeologi Yogyakarta)
}

\section{Prasasti Sebagai Artefak}

Manfaat prasasti sebagai salah satu sumber informasi yang terpenting dalam studi sejarah Indonesia kuna kiranya tidak perlu diperdebatkan kembali. Riwayat pemanfaatan prasasti di Indonesia, atau lebih sering disebut dengan studi epigrafi, sebagaimana yang dipaparkan oleh Wibowo (1992) dan juga oleh Suhadi (1982) memper. jelas pernyataan di atas. Lebih dari itu, melalui pengalaman pribadinya, Boechari (1977) menunjukkan pula bahwa dari studi prasastı telah memperluas pengetahuan kita mengenal segi-segi kehidupan kuna di Indonesia.

Melalui tulisan yang dicetak pertama kali tahun 1976, A.S.Wibowo (1992) menguraikan ragam segı kehidupan yang dihadirkan oleh para pakar dan pemerhati epigrafi dan sejarah Indonesia kuna sejak paroh pertama abad XIX. Menurutnya, semula hasil pembacaan dan tafsiran yang dilahirkan atas prasasti-prasasti di Indonesia masih belum terfokus arahnya. Namun studi atas prasasti pada paroh kedua abad XIX sampai dengan awal abad $X X$ telah memperlihatkan fokus yang nyata yaitu segi-segi Indianisası di Nusantara (Jawa) sebagaimana yang nampak pada kafran Kern, Cohen Stuart, Holle, Brandes, dan Krom. Telaah oleh Bosch sesudahnya belum beranjak banyak dari kecenderungan sebelumnya, namun memperlihatkan minat yang tınggı pada aspek agama dan kesenian Indonesia kuna. Lebih lanjut kajian sosiopolitik dan sosıo-ekonomi dikembangkan oleh Stutterheim sampai dengan medio abad XX ketika Casparis tampil dengan dominası karya-karya sejarah politiknya. Sejaman dengan era Casparis, kajian epigrafi oleh Damais menghasilkan sumbangan yang berharga bagı upaya untuk mengkonversikan pertanggalan prasasti dari tarikh Saka ke tarikh Masehi.

Penelitian epigrafi dan sejarah kuna oleh para pakar dan pemerhati di masa kemudian masih memperlihatkan kecenderungan-kecenderungan yang serupa dengan yang telah dimulai seJak pertengahan abad XIX di atas. Namun demikıan menurut hemat saya, berbagaı pendalaman telah dilakukan, misalnya saja tentang aspek pajak oleh Boechari, aspek genealogi penguasa-penguasa Majapahit oleh Hasan Djafar, dan masıh banyak yang lain. Sementara itu pada dua dekade terakhir ini suatu kecenderungan baru telah terlihat yaitu interpretasi yang menekankan pada gambaran tentang adanya proses pergeseran pada segi-segi sosial-ekonomı kehidupan masyarakat Nusantara kuna, sebagaimana yang dike- mukakan oleh Casparis (1983) dan Christie (t.th[b). Salah satu kesimpulan yang menarik darı telaah mereka, adalah gambaran yang mendalam tentang berlangsungnya suatu pergolakan dan pergeseran yang intens di level bawah dari struktur masyarakat jaman kuna, dalam kerangka proses tarik-ulur dengan lapisan sosial-politik di atasnya guna "memperebutkan" kewenangan politik dan pemanfaatan sumber-daya alam

Semua informasi dari jaman Indonesia ku. na tersebut mayoritas diperoleh berdasarkan proses penyadapan yang dilakukan atas apa yang tertulis pada prasasti, sesuai dengan hakekat data tekstual. Di lain pihak dipahami puia bahwa baik sebagai media maupun "message" (isinya), hakekatnya prasasti adalah produk darı kegiatan manusia di masa lampau.

Berdasarkan disiplin arkeologi Spaulding (1971) menyatakan bahwa subject matter dari arkeologi adalah artefak (dalam arti yang luas), yaitu seluruh benda yang mencerminkan kegiatan budaya manusia atau disebut juga budaya bendawi (material culture). Lebih jauh Hodder (1986:11) menyatakan bahwa ..."The writing of ink on paper is itself one type of material culture, and the inference of meaning from such evidence is equivalent to that for material objects in general" Berangkat dari gagasan ini sudah dapat ditetapkan bahwa prasasti juga merupakan kategori artefak, yang berarti pula potensial untuk dimanfaatkan bagi kajian arkeologi

Maksud kajian arkeologi di sini adalah meliputi apa yang disinggung oleh Spaulding (1971) dengan dimensi dari setiap artefak. Menurutnya artefak memiliki tiga dimensi, yaitu bentuk (fiorma), ruang (spatia), dan waktu (tempora). Analisis arkeologi didasari oleh interrelasi di antara ketiga dimensi tersebut, misalnya dimensi bentuk dengan waktu, dimensi waktu dengan ruang atau dimensi bentuk dengan ruang.

Sebagai obyek pengamatan, arkeologı memandang bahwa dimensi ruang tidak kalah pentingnya dibanding dengan artefak. Oleh karena itu dimensi ruang seperti situs (site) dan kawasan (region) seringkali dianggap sebagai data arkeologi, yang setara dengan artefak (Renfrew dan Bahn, 1991)

Dengan kerangka pandang bahwa prasast sebagai artefak, nampaknya dapat disampakan di sini telaah epigrafi, sebagaımana dırıwayatkan oleh A.S. Wibowo dan Machi Suhadi di atas telah banyak memperlihatkan penerapan analisis atas dimensi bentuk (media dan ISi prasastı) dan 
waktu, serta interrelasi di antara keduanya. Sementara itu analisis dimensi ruang, serta interrelasinya dengan dimensi bentuk dan waktu, relatif masih periu mendapatkan perhatian lebih jauh.

Memang harus diakui bahwa dimensi ruang untuk artefak prasasti tidak banyak memanfaatkan analisis kontekstual pada jenjang situs. Menurut hemat saya, telaah prasasti akan lebih bersesuaian dengan analisis distribusional pada jenjang kawasan. Patut dicatat di sini, bahwa bukan berarti sebelum ini studi distribusional atas artefak prasasti belum pernah dimanfaatkan oleh para ahli di Indonesia. Namun demikian berdasarkan pengamatan dapat disampaikan, bahwa studi semacam ini belum pernah dilakukan untuk menjawab suatu masalah arkeologi atau sejarah Indonesia kuna secara spesifik. Oleh karena itu makalah ini mencoba meyakinkan para ahli dan pemerhati epigrafi dan sejarah Indonesia kuna terhadap pentingnya informası yang dipetik dari fenomena distribusı ini sebagai 'data baru' yang potensial.

\section{Studi Distribusi}

Telah dikemukakan di atas bahwa studi epigrafi di Indonesia banyak didominasi oleh penerapan analisıs atas dimensi bentuk (media dan isi prasasti) dan dimensi waktu, serta interrelasi di antara keduanya. Interrelasi antara dimensi bentuk dan waktu tercermin, misalnya, pada hasil rekonstruksi perkembangan (seriasi) paleografi Jawa kuna, atau upaya yang dilakukan guna merekonstruksi perkembangan struktur politik Nusantara kuna di Jawa dan Bali

Walaupun demikian bukan berarti bahwa interreiasi antara bentuk prasasti dengan dimensi ruang belum pernah dibahas sebelumnya. Salah satu bahasan yang pernah dikemukakan, misalnya bahasan tentang lokasi temuan tipe-tipe bentuk prasasti tertentu yang pernah dikemukakan oleh Hari Untoro Drajat (1986). Telaahnya didasarkan atas prasasti koleksi Museum Nasional, dan salah satu interpretasinya adalah bahwa: prasasti batu dengan tipe bentuk berupa wadah berasal darı Jawa timur; prasasti batu dengan tipe bentuk batu alam berasal dari Jawa barat; sedang prasasti batu dengan tipe bentuk berupa tugu berasal dari Kalimantan dan Bangka

Sayangnya studi tersebut tidak berlanjut dengan memanfaatkan sampel yang lebih representatif dari luar koleksi Museum Nasional. Namun demikian hasil yang telah diperoleh sudah memberikan indikasi yang menjanjikan bagi studi tentang prasasti yang juga difokuskan pada dimensi ruang.

Studi distribusi artefak dalam arkeologi pada umumnya bermanfaat untuk merekonstruksi kegiatan pertukaran barang di antara dua atau lebih komunitas pada masa lampau (Earle \& Ericson, 1977) Studi ini juga potensial untuk melihat persebaran unsur-unsur suatu kebudayaan pada suatu kawasan yang lebih luas (Renfrew dan Bahn, 1991). Dari segi behavior, pola distribusi artefak bermakna pula untuk memahami pola arus energi pada suatu jenis barang, sejak berupa bahan baku di lokasi penambangannya sampai berupa barang bekas pakai di lokasi konsumen (Kusumohartono, 1993)

Menurut Hodder dan Orton (1976), poia distribusi artefak mudah dianalisis karena tenwakili dalam bentuk titik pada peta. Titik di atas peta mencerminkan keberadaan artefak di suatu lokasi. Namun demikian ketidakhadiran titik pada peta bukan selalu bermakna tidak pernah hadimya artefak yang dimaksud di lokasi tersebut. Mungkin saja artefak yang dimaksud belum ditemukan, atau mungkin sudah berpindah atau hancur sehingga tidak dapat dijumpai.

Berbagai jenis analisis keruangan dapat $d$. manfaatkan dalam studi distribusi artefak prasasti. Beberapa yang potensial, misalnya adalah analisis tetangga terdekat (nearest-neighbour analysis) guna mengkaji pola distribusi titik (artefak) pada peta (suatu kawasan): apakah berpola acak mengelompok, ataukah reguler/seragam (Hodder dan Orton, 1976; Kusumohartono, 1986). Distribusi artefak prasasti di suatu kawasan dapat pula dikaji melalui teknik analisis trend sufface, guna menampilkan pola kerapatannya dalam bentuk kontur di peta (Renfrew dan Bahn, 1991).

Guna mencapai efektivitas dari studi distribusi memang dibutuhkan dukungan analisis kuantitatif (Renfrew \& Bahn,1991). Titik-titik pada peta akan menjadi bermakna apabila dipahamı sebagai frekuensi munculnya artefak prasasti atau frekuensi munculnya variabel tertentu dari isi prasasti

\section{Potensi Dan Permasalahan}

Di atas telah disampaikan kemungkinan-kemungkinan yang dapat dipetik dari studi distribusional atas data prasasti. Berikut ını akan disajikan potensi dan permasalahan yang timbul di dalam mengaplikasikan studi ini. Identifikası terhadap potensi dan permasalahan tersebut terungkap berdasarkan hasil ujicoba yang telah dilakukan selama ini maupun berbagai kemungkinan yang diperkirakan akan muncul.

Aspek politik adalah salah satu segi kehidupan yang paling menarik dalam rekonstruksi sejarah Nusantara kuna. Dalam kaitan ini Paynter (1982) berpendapat, bahwa studi distribusı artefak dapat bermanfaat untuk merekonstruksi keberadaan pola dendritik dari aspek kewilayahan suatu struktur politik maupun ekonomi di masa laiu Prinsip ini pernah diterapkan sebagai kerangka pelingkupan wilayah studi penelitian Sriwijaya yang diselenggarakan oleh Puslit Arkeologi Nasional pada tahun 1992. Data utamanya adalah 
pola distribusı prasasti "kutukan" Sriwijaya yang dijumpai sepanjang DAS. Way Sekampung (Lampung), Musi (Sumatera Selatan), dan Batang Hari (Jambi).

Studi tersebut menginterpretasikan keberadaan pola dendritik berupa pergerakan energi, informasi, dan barang pada DAS-DAS di atas, pada Jaman kerajaan Sriwijaya di Sumatera bagian selatan. Tafsiran ini selaras dengan penelitian terdahulu tentang dukungan dari interaksi komunitas pedalaman dan pantai terhadap peradaban kuna di Palembang (Kusumohartono, 1989), serta bersesualan dengan hipotesis Miksic (1984) tentang keberadaan jaringan transportasi air, yang diperoleh melalui studi etnosejarah di DAS. Musi.

Enambelas tahun yang lalu Prof. Boechari pernah mengajukan tesis tentang prasasti berbahasa Sansekerta. Beliau berpendapat bahwa prasasti berbahasa Sansekerta dibuat untuk dikomunikasikan secara khusus kepada lapisan atas ma. syarakat Jawa kuna (Boechari,1978). Dengan asumsi bahwa prasasti tersebut berada tidak jauh dari komunitas pembacanya, maka pola distribusi dari artefak prasasti berbahasa Sansekerta merupakan data penting yang dapat mengindikasikan lokasi dan pola pemukiman dari lapisan atas masyarakat Jawa kuna.

Distribusi variabel tertentu dari informasi yang diperoleh berdasarkan pembacaan prasasti telah dicobakan pula untuk membantu merekons. truksi pola adaptasi lingkungan masyarakat Jawa kuna. Berdasarkan telaah mengenai pola munculnya informasi tentang perangkat irigasi dalam prasasti, terlihat kecenderungan bahwa informasi semacam itu berkaitan dengan kawasan Jawa timur dan sebaliknya tidak dijumpai pada prasasti yang ditemukan di Jawa tengah. Dalam kajian lebih lanjut, ditafsirkan bahwa fenomena ini mencerminkan hadirnya pola adaptasi teknologi pertanian-sawah abad XI-XV di Jawa dalam relasinya dengan kondisi iklim dan pola curah hujan yang berbeda secara spesifik antara Jawa tengah dan Jawa timur (Kusumohartono, 1991).

Telaah distribusional atas artefak prasasti juga bermanfaat untuk memahami pola pemilihan jenis batuan yang digunakail sebagai bahan pembuatan prasasti. Masalah ini menarik, mengingat prasasti merupakan artefak yang berfungsi sosioteknik di mana derajat pertimbangan-pertimbangan di seputar aspek teknologi yang bersifat relatif. Sejauh ini belum diketahui dengan pasti, adakah ketentuan yang baku tentang jenis batuan yang dapat atau harus digunakan sebagai bahan pembuatan media prasasti. Sejauh ini hanya diketahuı dengan pasti bahwa batuan yang dipilih untuk membuat prasasti pada jaman Indonesia kuna berasal dari jenis yang bervariasi.

Penjelasan atas masalah di atas dapat dijawab dengan mengoverlaykan peta pola distribusi jenis batuan (peta geologi) dengan peta pola distribusi jenis bahan prasasti batu pada kawasan yang sama. Artinya apabila pola kedua jenis data pada peta tersebut saling bersesuaian distribusinya, maka dapat ditafsirkan bahwa pemilihan batu sebagai bahan suatu prasasti lebih didasari oleh pertimbangan efisiensi atau praktis. Sebaliknya apabila tidak dijumpai adanya persesuaian antara pola distribusi kedua jenis data di atas, maka dapat ditafsirkan adanya semacam ketentuan atau panduan dalam memilih jenis batuan sebagai bahan prasasti.

Kajian distribusional ini juga berpotensi untuk menjawab pertanyaan masalah paleografi dalam studi epigrafi Indonesia kuna. Dalam makalahnya, Prasodjo (1992) mengungkapkan masalah tentang muncuinya variasi atau berbagai gaya huruf pada fase yang sama, dalam hal ini jaman Majapahit, yang belum mendapatkan penjelasan Fenomena ini terungkap karena dalam kajiannya Prasodjo telah melakukan interrelasi antara di. mensi bentuk dan waktu. Mungkin interrelasi antara dimensi bentuk dan ruang dapat memberikan 'data baru' yang diharapkan. Artinya, pola distribusi varian huruf pada jaman Majapahit kemungkinan mencerminkan adanya lokasi-lokasi pusat perkembangan budaya tulis pada jenjang wilayah atau sosial-politik yang.lebih rendah di masa itu.

Prasodjo (1992) juga mengajukan masalah lain berkaitan dengan penelusuran asal-usul huruf kuna di Nusantara, sebuah studi yang lebih spesifik dan rinci dari kerangka kajian tentang pengadopsian elemen budaya India oleh komunitaskomunitas kuna Nusantara. Untuk menjawab masalah tersebut, studi distribusional atas varian huruf pada prasasti direkomendasikan di sini, bersama dengan perhatian yang seimbang terhadap dimensi waktu dari keberadaan varian huruf tersebut. Dengan demikian secara sekuensial dapat diperoleh gambaran tentang perkembangan varian huruf di Nusantara, sejak bentuk yang sederhana di kawasan tertentu, sampai dengan persebaran dan pengaruhnya di kawasan lain

Menyımak uraian di atas, tentu saja studi ini akan lebih sesuai apabila memanfaatkan jenıs prasasti berbahan batu karena relatif lebih unma vable daripada prasasti logam atau lontar. Namun demikian, dalam kenyataanya beberapa prasast batu telah mengalami perpındahan tempat. Ber. hubung syarat utama dari studi distribusional adalah akurasi ruang (tempat/lokasi) darı artefak yang dikaji maka penentuan sampel prasastinya pun harus dilakukan dengan hati-hati.

Oleh karena itu sebelum analisis distribusional diselenggarakan, yang pertama-tama harus dikerjakan adalah melakukan identifikasi secara obyektif terhadap kesesualan lokası dari semiua sampel prasasti batu yang akan dianalisıs. Pengidentifikasian tersebut dilakukan berdasar pada 
laporan atau berita acara penemuan/pemindahan sampel yang bersangkutan, atau pencocokan nama sebutan prasasti dengan lokasi admistratif penemuannya (misalnya: Prasasti Dinaya dengan Dinaya di daerah Malang), atau pun kesesuaian nama tempat di dalam prasasti dengan kenyataan sekarang (misalnya: Prasasti Siwagrha dengan Candi Prambanan)

\section{Arkeologi Kesejarahan}

Dari pengalaman yang panjang melakukan penelitian dı Indonesia, peneliti dari Universitas Hull Inggris yaitu Jan Wisseman Christie (t.th.[a]), berkeyakinan bahwa penggabungan data epigrafi dan data arkeologi sangat bermakna bagi penelitian sejarah kuna di indonesia. Masalahnya, dengan mendayagunakan data epigrafi, paradigma dan metode sejarah atau arkeologikah yang sebaiknya diterapkan?

Darı pandangan disiplin sejarah, Gottschalk (1983) berpendapat bahwa aitefak sebenarnya merupakan data atau sumber sejarah. Pendapat ini didasari oleh pandangan bahwa artefak adalah hasil dari kegiatan atau peristiwa tertentu di masa lampau yang menjadi paradigma dari studi sejarah. Sedangkan dokumen atau teks adalah rekaman dari kegiatan atau peristiwa itu sendiri.

Dalam "kontroversi" ini, lebih jauh Hodder (1986) berpendapat bahwa arkeologi adalah bagian darı sejarah (sekaligus antropologi), apabila kita memahami bahwa: perilaku manusia dan budaya bendawı yang dihasilkannya adalah produk dari manusia yang tidak dapat lepas dari akar dan benang merah sejarahnya (sekaligus bersamaan dengan keberadaan dalam sistem kebudayaan)

Sebaliknya Hodder juga menegaskan bahwa sejarah dapat pula dianggap sebagar bagian dari arkeologi mengingat semua sumber sejarah, sepanjang berupa budaya bendawı, termasuk dalam kategori artefak yang berada dalam posisi sejajar bersama-sama dengan jenis data arkeologi yang laın. Menurut hemat saya tentu saja tiap disiplin --arkeologi, antropologi, atau sejarah-memilikı otoritasnya sendiri-sendiri, terutama apabila dipahamı bahwa masing-masing disiplin telah berproses dengan mengembangkan paradigma dan metodologi yang spesifik

Di dalam perkembangan disiplın arkeologi sendıri, pemanfaatan data tekstual, misalnya prasasti, untuk mengimplementasıkan paradigma arkeologı, diwadahı dalam studi arkeologi kesejarahan (historical archaeology). Hal inı dilandasi oleh prinsıp dari studı arkeologi kesejarahan itu sendırı yang dalam pengoperasiannya ... using both documents and objects as research toof' (Deagan, 1982). Dengan demikian prinsıp arkeologi kesejarahan merupakan gagasan dasar di balik rekomendasi yang dikedepankan dalam prasaran ını. Bagaımanapun juga pemanfaatan data tekstual dalam studi arkeologi kesejarahan, sekali lagı merujuk pada Deagan (1982) ... has been applied to the testing of a number of methods and assumptions commonly used in archaeological analysis and interpretation. Studi-studi keruangan dalam kaitannya dengan data tekstual telah dibuktikan manfaatnya oleh South (1977), maupun oleh Staski (1982) di dalam studi arkeologi kota.

Sebagai penutup, ada baiknya saya tekankan sekali lagi kemampuan dari studi/arkeologi kesejarahan. Studi ini mampu menangkap tiga kategori gejala observasi secara simultan, yaitu 1) memperhatikan pernyataan yang ditulis oleh manusia dari masa lampau tentang apa yang mereka perbuat; 2) sekaligus mempelajari pernyataan pemerhati (tulisan) dari masa lalu tentang apa yang diperbuat oleh manusia pada jamannya; dan 3) memperhatikan apa yang tercermın melalui obyek arkeologi tentang apa yang diperbuat oleh manusia pada masa lalu (Ibid.).

Menurut hemat saya kemampuan simultan ini harus dimanfaatkan secara optimal. Artınya, pengkotakan dan spesialisasi kaku yang memisahkan perhatian dan fokus pandangan ahli arkeologi di satu pihak dengan ahli sejarah (kuna) di pıhak lain, haruslah dihindarı. Dengan meyakini prasasti sebagai artefak maka seorang ahli arkeologi tidak harus alergi terhadap data tekstual dan sebaliknya seorang ahli sejarah (kuna) seyogyanya memandang bahwa makna penting prasastı tidak terbatas hanya pada teksnya semata namun juga memandangnya sebagai produk budaya bendawi dari masa silam yang potensial didekati dengan pandangan-pandangan arkeologis

\section{KEPUSTAKAAN}

Boechari, M. 1977. , Manfaat Studı Bahasa dan Sastra Jawa Kuna Ditinjau Dari Segi Sejarah dan Arkeołogi, Majalah Arkeologi Th. I (1) September 1977. Lembaga Arkeologi FSUl.

Boechari.,1978.,Bahan Kajian Arkeologi Untuk Pengajaran Sejarah, Majalah Arkeologi Th II (1) September. Lembaga Arkeologı FSUI

Casparis, J.G. de. 1983. Evolution of the SocioEconomic Status of the East Javanese VIIlage and Its Inhabitants. C.A.D.900-1400. dalam Taufik Abdullah (ed.) Papers of The Fourth Indonesia Dutch History Conference Yogyakarta:Gadjah Mada University Pres

Christie,Jan Wisseman.,t.th.(a) Trade, and Settlememnt in Early Java: Integrating The Eps. graphic and Archaeological Data, dalam I 
Glover, P. Suchitta, dan J. Villiers (peny.) Early Metallurgy, Trade and Urban Centres in Thailand and Southeast Asia. Bangkok White Lotus.

Christie, Jan Wisseman. t.th (b). Wanua, thani, paraduwan: The 'Disintegrating Village in Early Java?, naskah ketikan.

Deagan Kathleen. 1982. Avenues of inquiry in Historical Archaeology, dalam M.B. Schiffer (ed.) Advances in Archaeological Method and Theory: Vol. 5. New York: Academic Press

Drajat, Hari Untoro. 1986. Analisa Pendahuluan Bentuk Prasasti Batu, PIA IV. Jakarta: Pusat Penelitian Arkeologi Nasional

Earle, Timothy K. dan Jonathan E. Ericson. 1977. Exchange Systems in Archaeological Perspective.

Gottschalk, Louls 1983 . Mengerti Sejarah (terjemahan Nugroho Notosusanto), cetakan III. Penerbit Universitas Indonesia

Hodder, lan dan Clive Orton. 1976. Spatial Analysis in Archaeology. Cambridge: Cambridge University Press.

Hodder, lan., 1986., Reading the Past, Current Approaches to Interpretation in Archaeology Cambridge Cambridge University Press.

Kusumohartono, B. . Pemahaman Teoritik Tentang Analisis Kuantitatif Dalam Geografi Keruangan Dan Pemanfaatannya Bagi Telaah Arkeologi. Berkala Arkeologi, , - . https:/l doiorgl. I ba.vi

,1989 Potensi Lingkungan Regional dan Pertumbuhan Peradaban Kuna di Palembang. Naskah kontribusi bagi Laporan Penelitian Arkeologi Falembang 1990 yang diselenggarakan oleh Puslit Arkenas

1991. Aspek Adaptasi dalam Subsistensi Sawah Pada Jaman Indonesia Kuna di Jawa, dalam Proceedings Analisis Hasil Penelitian Arkeologi II 1988 Puslit Arkenas

1993. Artefak Logam Bagi Studi Pertukaran, Proceedings Analisis Hasil Penelitian Arkeologi IV 1991 Puslit Arkenas.

Miksic, J. N. (1984). Penganalisaan Wilayah Dan Pertumbuhan Kebudayaan Tinggi Di Sumatra Selatan. Berkala Arkeologi, 5(1), 9-24. https://doi.org/10.30883/ jba.v5i1.263
Paynter, Robert. 1982. Models of Spatial Inequality, Settlement Patterns in Historical Archaeology. New York: Academic Press.

Prasodjo, Tjahjono. 1992. Kecenderungan, Arah dan Prospek Studi Paleografi Klasik di Indonesia, dalam Pertemuan IImiah Arkeologi IV. Ikatan Ahli Arkeologi Indonesia.

Renfrew, Collin dan Paul Bahn. 1991 Archaeology. Theories, Methods and Practice. Thames and Hudson Ltd

Spaulding, Albert C. 1971. In The Dimensions of Archaeology, dalam James Deetz (ed.) Man's Imprint from The Past, Readings in The Methods of Archaeology. Boston Little Brown \& Co

Staski, Edward. 1982. Advances in Urban Archaeology, dalam M.B. Schiffer (ed.) Advances in Archaeological Method and Theory, Vol. 5. New York: Academic Press

Suhadi, Machi. 1982. Penelitian Prasastı di indonesia, dalam R.P. Soejono dkk (red.) Lokakarya Arkeologi Tahun 1978. Jakarta: Pusat Penelitian Arkeologi Indonesia

Wibowo, A.S. 1992. Riwayat Penyelidikan Prasasti di Indonesia, 50 Tahun Lembaga Purbakala dan Peninggalan Nasional (cetakan kedua, 1992). Pusat Penelitian Arkeologi Nasional Depdikbud 